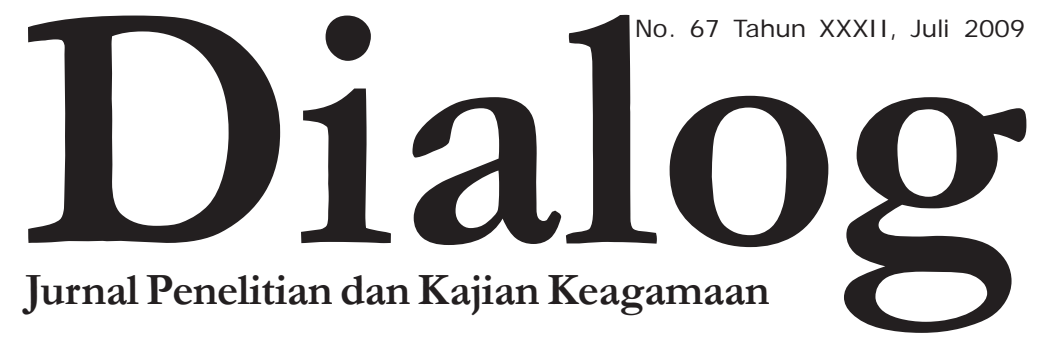

PERBANKAN SYARIAH DI INDONESIA

\begin{tabular}{|l|l|l|l|l|l|}
\hline Jurnal & $\begin{array}{l}\text { Nomor } \\
\text { Dialog }\end{array}$ & $\begin{array}{l}\text { Tahun } \\
\text { XXXII }\end{array}$ & $\begin{array}{l}\text { Halaman } \\
137\end{array}$ & Jakarta & ISSN \\
Juli 2009 & 0126-396X \\
\hline
\end{tabular}




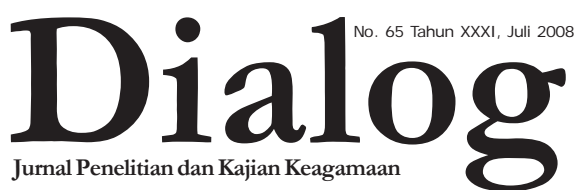

Pemi mpin Umum:

Prof. Dr. H. M. Atho Mudzhar, MA

Redaktur Aht :

Prof. Dr. H. Nasaruddin Umar, MA

Prof. Dr. H. Komarudin Hidayat, MA

Pemimpin Redaksi / Penanggung J awab

Drs. H. Syamsuddin

Waki l Pemi mpin Redaksi

H. Fanani Suprianto, SH., MM

Sekretaris Redaksi

M. Rosyid Fauzi, S.Si.

Dewan Redaksi

Prof. Dr. H. Abdurrahman Mas'ud

Drs. Amin Haedari

Prof. Dr. H. Maidir Harun

Drs. H. Mohammad Shohib, MA

Drs. H. Asmu'i, SH, MM

Chamdi Pamudji, SH., MM

Redaktur Eksekutif

M. Nasir, S.Th.I.

Redaktur Pelaksana

Moh. Rosyid Fauzi, S.Si

M. Nasir, S.Th.I

M. Adlin Sila, M.A

Abbas Jauhari, M.Ag

Admi ni strası

Drs. Dedy Curipno

Sutidjah

Desriyanti Nasution, S.IPI

Drs. H. Sahlani

Alamat Redaksi

Gedung Bayt Alquran Museum Istiqlal Komplek Taman Mini Indonesia Indah

Telp. (021) 87791444-87794982

Website:

www. balitbangdiklat.depag.go.id

Email:

info@depag.web.id

\section{PEIGITIR REDIKSL}

Karakteristik sistem perbankan syariah yang beroperasi berdasarkan prinsip bagi hasil memberikan alternatif sistem perbankan yang saling menguntungkan bagi masyarakat dan bank, serta menonjolkan aspek keadilan dalam bertransaksi, investasi yang beretika, mengedepankan nilai-nilai kebersamaan dan persaudaraan dalam berproduksi, dan menghindari kegiatan spekulatif dalam bertransaksi keuangan. Dengan menyediakan beragam produk serta layanan jasa perbankan yang beragam dengan skema keuangan yang lebih bervariatif, perbankan syariah menjadi alternatif sistem perbankan yang kredibel dan dapat dinikmati oleh seluruh

Jurnal Dialog diterbitkan oleh Badan Litbang dan Diklat Departemen Agama RI, sebagai media informasi dalam rangka mengembangkan penelitian dan kajiaan keagamaan di Indonesia. Dialog berisi tulisan ilmiah dan hasil penelitian dan pengembangan terkait dengan masalah keagamaan. Redaksi mengundang para peneliti agama, pengamat, cendekiawan, intelektual, dan akademisi untuk berdiskusi dan menulis secara bebas serta kreatif demi pengembangan penelitian maupun kajian keagamaan di Indonesia.

2 Dialog No. 67 Tahun XXXII, Juli 2009 
golongan masyarakat Indonesia tanpa terkecuali.

Fungsi Bank Syariah secara garis besar tidak berbeda dengan bank konvensional, yakni sebagai lembaga intermediasi (intermediary institution) yang mengerahkan dana dari masyarakat dan menyalurkan kembali dana-dana tersebut kepada masyarakat yang membutuhkannya dalam bentuk fasilitas pembiayaan. Perbedaan pokoknya terletak dalam jenis keuntungan yang diambil bank dari transaksi-transaksi yang dilakukannya. Bila bank konvensional mendasarkan keuntungannya dari pengambilan bunga, maka Bank Syariah dari apa yang disebut sebagai imbalan, baik berupa jasa (fee-base income) maupun mark-up atau profit margin, serta bagi hasil (loss and profit sharing).

Disamping dilibatkannya Hukum Islam dan pembebasan transaksi dari mekanisme bunga (interest free), posisi unik lainnya dari Bank Syariah dibandingkan dengan bank konvensional adalah diperbolehkannya Bank Syariah melakukan kegiatankegiatan usaha yang bersifat multifinance dan perdagangan (trading). Hal ini berkenaan dengan sifat dasar transaksi Bank Syariah yang merupakan investasi dan jual beli serta sangat beragamnya pelaksanaan pembiayaan yang dapat dilakukan Bank Syariah, seperti pembiayaan dengan prinsip murabahah (jual beli), ijarah (sewa) atau ijarah wa iqtina (sewa beli) (Farouk, 2009), dan lain-lain.
Dalam kajian Jurnal Dialog Edisi ini mencoba menyoroti perkembangan Perbankan Syariah di Indonesia yang beberapa tahun belakangan ini cukup mengalami perkembangan yang signifikan. Sehingga tidak sedikit bank konvensional yang membuka divisi syariah guna berebut nasabah yang kian meminati sistem perbankan syariah. Kajian Jurnal Dialog edisi ini diawali dengan tulisan Dr. Euis Amalia yang mengulas tentang Perbankan Syariah di Indonesia: Kontribusinya Bagi Perekonomian Nasional dan Peran Perguruan Tinggi dalam Rangka Akselerasi. Dilanjutkan dengan tulisan Muhammad Taufiki, M.Ag yang mengupas tentang Aplikasi Konsep Hilah dalam Pengembangan Produk Perbankan Syariah (Analisa terhadap Fatwa tentang Syariah Charge Card).

M. Adlin Sila, MA, peneliti di Badan Litbang dan Diklat Depag mencoba mengulas kemungkinan Bank Syariah Sebagai Bank Bagi Hasil? Ah. Azharuddin Lathif, M.Ag, MH, Dosen Fakultas Syariah dan Hukum UIN Jakarta menghadirkan tulisan tentang Analisis Yuridis Pengenaan Pajak Pertambahan Nilai (Ppn) Dalam Pembiayaan Murabahah di Perbankan Syariah. Sedangkan Prof. Dr. Abd. Rachman Mas'ud Kepala Puslitbang Kehidupan Keagamaan, melalui tulisannya mencoba menyoroti Etika Professional dan Ruh Agama di Awal Millenium. Yulizar D. Sanrego \& Aam S. Rusydiana dosen di Tazkia Institute 
menghadirkan tulisan tentang Peran Perbankan Syariah dalam Mendukung Umkm Pertanian. Kajian ini dilengkapi dengan tulisan Iyoh Masthiyah Peneliti Puslitbang Pendidikan Agama dan Keagamaan Badan Litbang dan Diklat Depag tentang Hak Milik dalam Islam Perspektif Ibn Taymiyah. Kajian dalam Jurnal Dialog edisi ini kian lengkap dengan hadirnya tulisan Yulianti Muhammad yang menganalisis Prospek Perbankan Syariah di Indonesia.

Di samping memuat artikel ilmiah, Jurnal Dialog edisi ini juga memuat laporan hasil penelitian oleh
Dr. Anwar Abbas tentang Ekonomi Islam dan Pemberdayaan Ekonomi Rakyat; Studi Kasus Pemberdayaan Melalui Koperasi Pondok Pesantren Sidogiri Kab. Pasuruan Jawa Timur. Kajian ini diakhiri dengan telaah buku yang mengulas buku karya Drs. Cik Basir, SH, MHI, 2009. Penyelesaian Sengketa Perbankan Syariah di Pengadilan Agama dan Mahkamah Syar'iyah. Semoga kajian yang dihadirkan Jurnal Dialog edisi ini memberikan manfaat yang berarti bagi para pembaca, khususnya dalam kajian Perbankan Syariah di Indonesia. Selamat Membaca!

Redaksi 


\section{DIPTIRISI}

\section{TOPIK}

PERBANKAN SYARIAH DI INDONESIA:

Kontribusinya Bagi Perekonomian Nasional dan

Peran Perguruan Tinggi dalam Rangka Akselerasi

Euis Amalia -6

APLIKASI KONSEP HILAH

DALAM PENGEMBANGAN PRODUK PERBANKAN SYARIAH

(Analisa terhadap Fatwa tentang Syariah Charge Card)

H. Muhammad Taufiki -20

BANK SYARIAH SEBAGAI BANK BAGI HASIL: MUNGKINKAH?

M. Adlin Sila -30

ANALISIS YURIDIS PENGENAAN

PAJAK PERTAMBAHAN NILAI (PPN)

DALAM PEMBIAYAAN

MURABAHAH DI PERBANKAN SYARIAH

Ah. Azharuddin Lathif -52

ETIKA PROFESSIONAL DAN RUH AGAMA

DI AWAL MILLENIUM

Abd. Rachman Mas'ud -69

PERAN PERBANKAN SYARIAH DALAM

MENDUKUNG UMKM PERTANIAN

Yulizar D. Sanrego \& Aam S. Rusydiana -74

HAK MILIK DALAM ISLAM PERSPEKTIF IBN TAYMIYAH

Iyoh Masthiyah --90

PROSPEK PERBANKAN SYARIAH

DI INDONESIA: CERAH ATAU BURAM?

Yulianti Muhammad --101

\section{PENELITIAN}

EKONOMI ISLAM DAN

PEMBERDAYAAN EKONOMI RAKYAT; Studi Kasus Pemberdayaan Melalui

Koperasi Pondok Pesantren Sidogiri Kab. Pasuruan Jawa Timur

Anwar Abbas -117

\section{BOOK REVIEW}

PENYELESAIAN SENGKETA PERBANKAN SYARIAH

(Di Pengadilan Agama dan Mahkamah Syariah)

R. Meilani Dewi - 132 


\title{
Etika Professional dan Ruh Agama di Awal Millenium
}

\author{
OLEH : Prof. H. Abd. Rachman Mas‘ud, Ph.D. ${ }^{1}$
}

\begin{abstract}
:
The concept of professional ethics is partly comprised of what a professional should or should not do in the work place. It also encompasses a much greater part of the professionals life. If a professional is to have ethics then that person needs to adopt that conduct in all of his dealings. There are professional codes of ethics to consider and adopt in the way professionals conduct themselves in and out of the work place. This article explaines things that are included in professional ethichs, consist of concepts like: efficiency, professionalism, working well, little waste, diligence, punctuality, frugality, humbleness, spirit of prestige, need for achievement, open-minded, self-discipline and responsibility, self-reliance and the interpretation of religious thoughts. These ethics will be the basis of national development and needs to be reidentified in this 21st century.
\end{abstract}

Masyarakat kita cenderung melihat dan memahami kata etika sebagai budi pekerti, akhlaq, sopan santun, atau tawadlu'. Yakni kode etik yang berhubungan dengan pemberian hormat secara khusus kepada generasi tua, guru, pimpinan, dan orang-orang yang dianggap terhormat dalam

${ }^{1}$ Penulis adalah Kepala Pusat Kehidupan Keagamaan, Badan Litbang dan Diklat Depag RI, pembimbing disertasi di beberapa UIN, termasuk di UPI Bandung, mantan rektor UNSIQ Jateng, Universitas Sains dan al-Quran, mantan direktur pendidikan Tinggi Islam, Depag RI, mutakharrij madrasah Aliyah Qudsiyah kudus 1980, alumni UCLA (The University of California Los Angeles), 1997 dengan Fulbright scholarship, dan pernah memperoleh kesempatan posdoct research di beberapa Universitas AS 2001-2002, dan mengajar di Salve Regina University, Newport Rhode Island tahun 2004 struktur masyarakat. Arti etika yang sebenarnya adalah systematic code of moral principles: ${ }^{2}$ serangkaian undang-undang atau peraturan yang sistematis tentang prinsip-prinsip moral. Dengan kata lain etika adalah prinsip-prinsip moral atau nilai-nilai sosial yang berkembang, dimiliki dan dijunjung tinggi dalam masyarakat tertentu dari waktu ke waktu.

Profesional biasanya mengacu pada kelompok menengah (middle class) yang pekerjaannya menuntut keahlian tehnis dan pengetahuan tertentu, serta kedisiplinan tinggi. Talcott PARSONS (1964), ahli sosiologi kenamaan Amerika, menghubungkan

${ }^{2}$ International Encyclopedia of the Social Sciences, dibawah judul artikel Ethics, volume 5-6, (New York: 1968), halaman 157-167.

Dialog No. 67 Tahun XXXII, Juli 2009 69 
profesionalisme dengan ciri-ciri pengetahuan khusus dan altruism serta menambahkan bahwa sebagai hasil keahlian dan pengetahuan seseorang, kaum profesional mengalahkan atau lebih mempunyai otoritas dibanding masyarakat awam dan bahwa ciri-ciri kaum profesional sangat jelas memperkuat lembaga-lembaga modern.

Dengan kata lain profesionalisme menandai secara tegas ciri-ciri modernisasi. Modernisasi selama ini sering diidentikkan dengan dunia Barat yang sangat diwarnai dengan kehidupan sekuler. Sejak abad lalu Masyarakat Barat sering menggemborkan slogan "God is dead" dengan faham dasar mereka yang liberalisme, individualisme, dan materialisme. ${ }^{3}$ Jika isme di Amerika bisa dikenali melalui mata uang dolar yang berbunyi "pada Tuhan kami beriman," in God we trust, tapi pemandangan sesungguhnya yang terjadi disana adalah in money we trust, kepada uang kami beriman atau

\footnotetext{
${ }^{3}$ Faham Unitarianism di US disponsori oleh Thomas Jefferson (1743-1826), salah seorang America's Founding Father yang paling berpengaruh merancang Amerika sekuler, dalam pidato bersejarahnya ia mengatakan: "Saya berharap dengan penuh keyakinan bahwa generasi saat ini akan memandang faham liberal menjadi agama masyarakat di AS," I confidently expect that the present generation will see Unitarianism become the general religion of the United States. Bahkan sebelumnya, ia mengkritik agama yang ada sebagai sebuah khayalan lelucon tentang Tuhan yang sama dengan Cerberus, satu badan tiga kepala, The hocus pocus phantasm of a God like another Cerberus, with one body and three heads. Pandangan semacam ini berdampak pada absennya pendidikan agama dalam kurrikulum sekolah negeri. Karena agama dipandang sebagai masalah pribadi sedangkan sekolah sebagai masalah publik maka kedua kehidupan yang berbeda ini tidak boleh dicampuradukkan.
}

70 Dialog No. 67 Tahun XXXII, Juli 2009 bertawakkal. Istilah money talks ${ }^{4}$ uang berbicara (yakni uang menjadi pertimbangan terpenting dalam kehidupan sosio-politik), demikian populer di negeri Obama. Dengan demikian selama ini konsep modernisasi sering memiliki konotasi sekularisasi dalam masyarakat materialisme ini.

Tapi konsep modernisasi yang diidentikkan hanya dengan Barat ternyata tidaklah begitu tepat. Bahwa Jepang modern, negara yang bersikeras mempertahankan tradisi, sejak abad 19 secara aktif mendukung aspek-aspek tradisional bangsa untuk tujuan politis dan dalam rangka mempertahan ciri nasional Jepang, jelas menghapus kesan bahwa negara modern hanya milik dunia Barat. Begitu pula di negaranegara mayoritas Muslim seperti Pakistan, Malaysia, dan Indonesia, konsep modernisasi dan agama nampaknya saling mendukung hand in hand. Dengan demikian konsep modernisasi yang diidentikkan dengan sekularisasi adalah ahistori (tidak memperoleh pembenaran sejarah).

Kita yang sudah terlanjur menamakan diri sebagai masyarakat akademis, harus mampu berdialog dengan kebudayaan modern dan secara aktif mengisinya dengan substansi dan nuansa-nuansa yang sesuai dengan kepribadian bangsa kita. Hal ini hanya bisa dilakukan bila kita memahami arus globalisasi dan merespons secara benar. Benarlah apa yang dikatakan futurolog John Naisbitt: "The new source of power is not money in the hands of a few but information in the hands of many".

\footnotetext{
${ }^{4}$ Sindiran atau kritik dalam bahasa Arab terhadap tendensi ini adalah "Al-Fulus yuhyinnufus" (uang atau harta sering membangkitkan semangat kehidupan).
} 
(Kekuatan baru dewasa ini bukanlah harta karun di tangan segelintir manusia tapi jaringan informasi di tangan banyak manusia). Relevan juga apa yang dikatakan ahli manajemen Amerika, Drucker bahwa: "The productivity of knowledge became the key to productivity, competitive strenght, and economic achievement. Knowledge has already become the primary industry, the industry that supplies the economy the essential and central resources of production." ${ }^{5}$ (Produktivitas ilmu pengetahuan telah menjadi kunci produktivitas, keampuhan daya saing, dan prestasi ekonomi. Ilmu pengetahuan telah menjadi industri utama, yakni industri yang melengkapi ekonomi dengan sumber-sumber produksi utama yang maha penting).

Telah dimaklumi bersama bahwa Indonesia bukanlah negara sekuler tapi juga bukan negara agama. Kendatipun demikian, perkembangan bangsa kita menunjukkan bahwa Indonesia sangat mendukung tinggi kehidupan beragama secara konstitusional dan institusional. Masyarakat Indonesia yang relijius dan modern adalah tujuan kita bersama. Sangat menyedih-kan bahwa masyarakat Indonesia yang relijius dewasa ini masih terpuruk dalam himpitan krisis dan terbelakang dalam pelbagai aspek kehidupan dikarenakan ketertinggalan informasi dan sains, serta penyakit mentalitas bangsa.

Dengan supremasi knowledge dan information yang dikuasai oleh negaranegara maju, negara-negara dunia ketiga, termasuk Indonesia, masih terus bergantung kepada dunia Barat dalam hampir semua sektor kehidupan: pertahanan dan persenjataan, komunikasi dan informasi, ekonomi, pendidikan

\footnotetext{
${ }^{5}$ John Naisbitt, Megatrends (1982).
}

dan pengembangan ilmu pengetahuan. Ketergantungan global dunia ketiga adalah satu realitas yang tidak bisa dihindarkan.

Pengalaman menunjukkan bahwa arus informasi global ternyata tidak seimbang dengan dominasi informasi yang datang dari budaya Barat. Keadaan ini menimbulkan dominasi kultural atau imperialisme budaya. Globalisasi berimplikasi Westernisasi yang berakibat budaya lain tergilas. Dalam kondisi ini tidaklah heran jika para ilmuwan meramalkan adanya perang ideologi-ideologi dunia seperti Islam yang senantiasa dipertentangkan dengan Barat, baik oleh ilmuwan Barat seperti Samuel Huntington dalam tulisannya, the Clash of Civilization, atau oleh sebagian Muslim sendiri karena over reaksi terhadap pendekatan Huntington.

Bagi umat beragama, hususnya umat Islam, disinilah arti penting implementasi hadis Nabi yang sangat populer: "Talab al-ilm faridlatun ala kulli muslimin wa muslimatin " mencari ilmu adalah satu kuajiban bagi setiap Muslim dan Muslimah. ${ }^{6}$ Konsekuensi logis dari

${ }^{6}$ Surat pertama al-Qur'an yang diturunkan pada Nabi Muhammad saw. adalah surat iqra' yakni satu seruan pengembangan intelektual yang ternyata telah terbukti dalam sejarah mampu merubah peradaban manusia di dunia ini dari masa kegelapan moral dan intelektual dan membawanya kepada peradaban tinggi yang sesuai dengan petunjuk Ilahi dari abad 7 sampai abad $12 \mathrm{M}$. Dalam ayat ini pula Allah memperkenalkan qalam, alat tulis menulis. Sesungguhnya Allah adalah master-Nya Nabi Muhammad, sedangkan Nabi Muhammad adalah mutlak gurunya umat Islam di seluruh dunia. Perlulah kiranya direnungkan dan dilaksanakan ayat al-Qur'an yang indah ini, yang menekankan pentingnya arti kegiatan membaca dalam proses belajar mengajar dalam arti yang luas.

Dialog No. 67 Tahun XXXII, Juli 2009 
ajaran dasar Nabi ini adalah jika umat Islam tidak menguasai knowledge yang Nabi menyebutnya sebagai fardlu 'ain, maka kondisi umat akan menyedihkan sebagaimana yang kita lihat dewasa ini. Yakni kesengsaraan dan marginalisasi umat Islam oleh negara-negara super power terus berlangsung. Oleh karena itu, program intelektualisasi, profesionalisasi di lingkungan kita merupakan satu keniscayaan.

Etika profesional yang merupakan nilai-nilai dasar modern pada umumnya mempunyai ciri-ciri sebagai berikut:

1. Efficiency, working well, little waste atau berdaya guna, anti mubazir

2. Diligence, attentive and busy, kesibukan yang terarah terfokus

3. Orderliness, tartib, nizam

4. Punctuality, ketepatan waktu, menjunjung tinggi ajaran wal-'asri

5. Frugality, humbleness, kebersahajaan.

6. Kejujuran yang ketat, scrupolous honesty yg berakibat dalam jangka panjang meningkatkan efficiency dalam hubungan sosial dan ekonomi.

7. Rasionalitas dalam keputusankeputusan tindakan, membebaskan diri dari ketergantungan kebiasaan yang statis, kesetiaan kelompok, serta favoritism, dari fanatic belief yang tidak rasional atau fanatisme buta dan prejudice.

8. Siap siaga akan perubahanperubahan, isti'dad

9. Kewaspadaan akan kesempatankesempatan karena mereka hidup dalam a changing world.

10. Usaha energetic, sesuai semangat dan ajaran jihad

11. Integritas dan self-reliance: amanah

72 Dialog No. 67 Tahun XXXII, Juli 2009
12. Kerjasama, bukan membatasi tapi mengarahkan ulang upaya-upaya egoistik untuk kesejahteraan sosial. Menerima tanggung jawab untuk kesejahteraan community dan negara.

13. Keinginan untuk melihat kedepan, antisipatif. $^{7}$

Yang perlu diperhatikan adalah apakah ciri modern di atas secara substantif berbeda dengan inti ajaran dasar dan ruh agama? Agaknya secara konseptual, ajaran Islam justru mendahului prinsip-prinsip modern dan profesional. Tapi dalam realita, kehidupan umat beragama dewasa ini masih sarat dengan nilai-nilai pasif. Persoalannya adalah bagaimana mengaktifkan nilai-nilai tersebut, yakni dari passive value system ke aktif dan dinamis. Di sini perlu dibedakan antara what it is (baca prilaku sebagian Muslim) dan what it should be (baca Islam). Di sinilah perlunya menginterpretasi kembali ajaran-ajaran dasar agama. Ajaran sabar misalnya, selama ini lebih banyak difahami sebagai aspek "nerimopasrah" ketimbang berusaha keras. Padahal kata sabar dalam al-Quran lebih didominasi kata kerja (verb) ketimbang kata sifat. Dalam konteks profesionalisme, sabar semestinya diterjemahkan sebagai "loyal to the standard principles." Yakni konsisten dengan prinsip-prinsip standar yang harus dijunjung tinggi oleh pribadi, masyarakat, dan lingkungan bersama.

Budaya bangsa kita di samping memiliki unsur-unsur positif harus diakui juga mengandung unsur-unsur negatif. Mental agraris agaknya cukup mewarnai mentalitas manusia

\footnotetext{
${ }^{7}$ Ciri-ciri moderen secara rinci diantaranya bisa dilihat dalam Gunnar Myrdal, Asian Drama.
} 
Indonesia. Cara pandang agraris mencerminkan sikap statis, tidak produktif karena pasrah pada siklus waktu. Bahkan sampai kinipun masih dirasakan sisa-sisa feodalisme dalam bentuk yang beragam. Pengajar yang merasa paling pintar dan benar sendiri adalah feodal yang bersembunyi dalam majlis terhormat. Penguasa yang asyik dengan kekuasaannya hingga tidak mendengar jeritan rakyat kecil adalah feodal abadi dan mengingkari hukum alam: Sunnatullah.

Selain penyakit di atas, sifat-sifat yang harus kita berantas adalah mentalitas yang meremehkan mutu, suka menerabas, tak percaya diri, tidak berdisiplin murni, dan suka mengabaikan tanggung jawab. Tegasnya tradisi kita masih terpolusi dengan berbagai macam penyakit. Demikian hasil berbagai penelitian dan kajian-kajian ilmiah yang bisa dipertanggungjawabkan.

Jika kemerdekaan Indonesia tidak lepas dari moral dan religious support, yakni agama sebagai prime-mover, penggerak utama, kemerdekaan atau manusia merdeka, tentu dewasa ini kita harus jujur bertanya apakah agama sudah mampu memberantas korupsi, kolusi, ketidakadilan, dan penyakitpeyakit sosial lainnya. Sangat tidak kita harapkan jika agama akan dijadikan alat legitimasi untuk pembangunan di satu pihak, dengan melupakan penyakitpenyakit pembangunan, dan reformasi sosial yang lebih esensial.

\section{Penutup}

Berangkat dari uraian di atas, beberapa etika profesional yang melandasi sekaligus menjadi ruh pembangunan bangsa, di abad 21 ini perlu dikaji dan direnungkan kembali. Dua kata kunci self-reliance dan the reinterpretation of religious thoughts yakni kemandirian bangsa dengan kekuatan dari dalam dan penafsiran kembali ajaran-ajaran agama adalah pesan utama tulisan ini. Upaya pemecahan masalah di atas barangkali tidak lepas dari poin-poin berikut:

1. dibutuhkan perumusan etika nasional (profesional) yang dibangun dari percikan agama yang mengakomodasi budaya lokal dan berorientasi ke depan: yakni Indonesia yang relijius dan modern. Sikap dan gairah berprestasi, need for achievement, terbuka, disiplin, dan bertanggung jawab adalah prinsipprinsip yang harus ditegakkan.

2. Jika dirasakan bahwa selama ini ajaran agama masih bersifat normatif dan pasif, maka upaya penciptaan iklim yang kondusif terhadap aktualisasi sistem nilai dalam rangka reformasi total, bersih lingkungan, gerakan disiplin nasional, dan memusatkan manusia sebagai aktor perubahan merupakan proses yang tidak pernah dan tidak boleh terhenti. Dengan kata lain, putus asa terhadap realitas sosial yang korup tidak ada dalam vocabulary masyarakat relijius Indonesia.

3. Upaya-upaya pengembangan masyarakat dengan misi liberation dan empowerment (pembebasan dan pemberdayaan) umat perlu ditegakkan secara kontinu, terpadu dan bertanggung jawab.[] 